Abstracta Iranica Abstracta Iranica

Revue bibliographique pour le domaine irano-aryen

Volume 22 | 2001

Comptes rendus des publications de 1999

\title{
Haft mard, haft dāstān. Tehrān, Rāhiyān-e andīše, 1378/1999, 122 p. [Sept hommes, sept nouvelles]
}

\section{Christophe Balaÿ}

\section{(2) OpenEdition}

1 Journals

\section{Édition électronique}

URL : http://journals.openedition.org/abstractairanica/37123

DOI : 10.4000/abstractairanica.37123

ISSN : 1961-960X

Éditeur :

CNRS (UMR 7528 Mondes iraniens et indiens), Éditions de l'IFRI

\section{Édition imprimée}

Date de publication : 15 mai 2001

ISSN : 0240-8910

Référence électronique

Christophe Balaÿ, « Haft mard, haft dāstān. Tehrān, Rāhiyān-e andīše, 1378/1999, 122 p. [Sept hommes, sept nouvelles] », Abstracta Iranica [En ligne], Volume 22 | 2001, document 540, mis en ligne le 15 février 2010, consulté le 13 octobre 2020. URL : http://journals.openedition.org/abstractairanica/ 37123 ; DOI : https://doi.org/10.4000/abstractairanica.37123

Ce document a été généré automatiquement le 13 octobre 2020

Tous droits réservés 


\section{Haft mard, haft dāstān. Tehrān, Rāhiyān-e andī̌se, 1378/1999, 122 p. [Sept hommes, sept nouvelles]}

\section{Christophe Balaÿ}

1 À la suite de Haft zan haft dāstān, (Sept femmes sept écrivains), qui avait fait connaître sept femmes, jeunes écrivains, encore peu connues du public, le même éditeur poursuit son œuvre avec sept écrivains-hommes : cette fois, à l'exception d'Amīr-Ḥasan Čeheltan et de Šahriyār Mandanīpūr, ce sont des écrivains plutôt âgés. Tous ont derrière eux une belle carrière de romancier ou de nouvelliste, y compris les plus jeunes. «Sept femmes sept écrivains ", avant chaque nouvelle, donnait la parole à l'auteur qui racontait en quelques lignes son expérience de l'écriture. "Sept hommes sept écrivains» se contente d'une date de naissance et de quelques éléments de bibliographie. On regrettera seulement que cette bibliographie ne soit pas plus complète ni plus précise.

\section{INDEX}

Thèmes : 11.1.2. Littérature persane moderne

\section{AUTEURS}

CHRISTOPHE BALA $\ddot{Y}$

IFRI - Téhéran 